\title{
Protecting the Rights of Victims of Rape and Incest: A Professional Opinion to Challenge Discussion
}

\author{
*Scott A Johnson \\ licensed psychologist, USA \\ Submission: September 03, 2016; Published: September 16, 2016 \\ *Corresponding author: Scott A Johnson, Licensed Psychologist, USA, Tel: 612 269-3628; Email: scott@forensicconsultation.org
}

\section{Opinion}

As I watched a news program one night I was appalled by the republicans push to end funding for the victims of rape or incest to obtain an abortion. For female victims unable to afford an abortion, public funding is planned to be cut and there has been a constant push to illegalize abortion in general. Women who can financially afford an abortion would not likely be impacted if public funding is withheld. However, women without financial means would be revictimized by being forced to either carry the child to term or terminate with less legal and less medically safe procedures. Of course the republicans pushing for these changes are almost exclusively men. Remember when Dick Cheney was anti-homosexuality until of course his daughters publically announced their homosexuality? Perhaps if more right wing and conservative families experienced rape and incest more often and more publically, then the push to prevent victims from public funding for the option of abortion.

So what now? Should we simply allow sexual offenders to impregnate females and to subject the victims to being forced to carry, give birth to, and raise a child born of a violent and repulsive act? Perhaps we should allow sexual offenders to have parental rights to the victim's child, or better yet to produce as many children as possible and have no financial responsibility for their children? Or maybe we should just legalize rape and incest Perhaps that would simply make more sense. Let men rape and have sex with adolescents and even with children. Maybe that is the answer. And on the other side, if rape victims are forced to give birth to a child born of a violent crime, and to raise the child for life, then perhaps the sex offender should have to forfeit all they own to pay for the child or go to prison for a minimum of twenty-six years (that is the average age children remain in the home). At least then the rape victim and child born of rape maybe have some financial support from the rapist daddy.

\section{Imagine This...}

Perhaps sexual offenders should target only right-wing republican females to rape and molest. Imagine the legacy for the sex offender, impregnating and being baby daddy to a child.
Wow, perhaps even marry the victim and let's just not care if the victim is a minor or not, she should have to bear the child and marry the sexual offender. And the sexual offender then would become part of the republican's family, imagine the financial wealth the sexual offender could then access. Unbelievable! I am in no way condoning, encouraging or supporting any act of violence, rape or incest. I am just thinking out-loud encouraging discussion on how right-wing extreme views of the limitations of rape and incest victims in dealing with the option of abortion, the morning after pill, or carrying the child to term. It seems that the opinion of others carries more power than the opinion of the rape and incest victim.

I thought being an American meant and even guaranteed that all people would be treated equally, that all people deserved equal protection from harm regardless of financial status. Regardless of whether or not a person believes in a woman's right to choose an abortion, victims deserve special and unequivocal protection, unless of course you blame the victim for being a victim of a heinous crime. If a State or other government agency prohibits a victim's right to accessible and affordable abortion services or the morning after pill, then perhaps the government agency should assume full responsibility for the child's expenses until age 26, including diapers, child care, food, and education expenses (including college). If a government or religious agency forces victims of rape or incest to carry the child of a violent act to term, then the agencies and churches should be held fully financially responsible. It is easy to put forth expectations and laws and intimidation against victims when you are not responsible for the outcome.

Some people believe that when a victim of rape or incest becomes pregnant that it is somehow God's will. Therefore, the product of a violent and perverted act is God's will without exception. Really? If you are changing a tire on the freeway and are hit and killed by a car, was that God's will as well? Did God want you to die? Really? Either God is loving or vindictive, it cannot be both. As a Christian, I do believe in "free-will", and that includes God's choice to allow people to exercise "free-will" in how they live their life and how they act. That is to say that 
people can choose to engage in peaceful or violent behavior regardless of God's will for peace and love.

As a forensic psychologist and professor I understand that rape and incest may result in sperm and ovum coming into contact and approximately fifty percent of the time a pregnancy results. God may or may not play a role. Biology is in and of itself fascinating and at times both predictable and unpredictable. Does God intercede to cause or prevent pregnancy? That is a difficult question because there is no answer. Many people conceive and turn out to be ineffective or abusive parents. Was that God's will? Healthy and loving people sometimes try for years to conceive before becoming pregnant. Was that God's will or simply chance? I do not for a moment believe that any God, of any religion would cause the pregnancy of a rape or incest victim. That would be a cruel and insufferable God. Stop blaming God for the pregnancy of rape and incest victims. Victims who become pregnant as a result of rape or incest are simply further victimized, forced to make a decision about carrying to term a baby born of a violent and heinous act or terminating the pregnancy and dealing with that decision for the rest of their life. Either way not an easy decision for the victim. However the decision seems easy and uncomplicated for politicians who decide that a victim should not have the right to choose about their body and about how to deal with the ramifications of rape or incest.

To not allow the victim of rape or incest to choose to terminate a resulting pregnancy is simply unacceptable. To allow victims who can afford an abortion to receive one but the victim without financial means is forced to continue with the pregnancy is simply unacceptable and is blatantly a re-victimization of the victim. There is no other way to look at it. And of course there is another option victims should be offered at no charge-the "morning-after pill". The "morning after pill" does not terminate a pregnancy but if taken within 72 hours after a rape or incestuous act it works to prevent fertilization and implantation. Yet some religious groups also call this option unacceptable as well.

Imagine one of your family members, a daughter, sister, wife, or your girlfriend being the victim of rape or incest. Imagine the psychological, physical, spiritual, and other trauma that results. The victim wonders what they did to deserve being a victim, wonders if in some way it was their own fault. Even young children, victims of molestation and incest, ask themselves the same and similar questions. And what is the answer? They did absolutely nothing to ask for or in any way deserve to be the victim of rape or incest.

As an expert on sexual offenders and predators I have come to understand that the offender makes their own decision. In fact, the sexual offender made their decision to take sex, to use sex as a weapon, and to harm and at times kill their victims because of numerous factors, but one primary factor: they simply made the decision to do what they wanted to do to the victim without any regard for the victim's safety or well-being. The sex offender makes a conscious choice to offend. Rape and molestation are never an out-of-control behavior- ever. The victim's behavior did not significantly influence the sexual offender's decision to rape or commit incest and nothing can make or cause a sex offender to offend except themselves.

So again I am perplexed that victims of rape and incest are blamed for being a victim. That somehow the victim simply needs to shut-up and have a baby that resulted from a violent and unreligious and ugly event, an act that even God would not condone in any way. The republicans have waged a war on victims of sexual offenses as well as on the health care women have a right to receive. Also no one religion is the "American" religion. America is "one nation under God", but not a specific religion. Yet Mitt Romney representing the Mormon church or even the Catholic church believe that they are both the chosen religion of America and therefore they should set the morals and values for all Americans. That is ridiculous.

\section{Conclusion}

I encourage everyone to take a stand on the above concerns. No one deserves to be the victim of rape or incest and no one can in any sane consciousness believe that God caused the victim to become pregnant. We have the means to allow females the right to choose what they do with their body and that should always include the right to terminate a pregnancy resulting from rape or incest without exception to financial concerns. Please stand up for the rights or women, of victims. In addition, set higher standards that men need to take responsibility for their actions, including helping victims and ceasing abusive and violent behavior. 